\title{
Evaluation of Operation of Lake Tana Reservoir Future Water Use under Emerging Scenario with and without climate Change Impacts, Upper Blue Nile
}

\author{
Getachew Tegegne $^{1}$, Dr. Ing.Dereje Hailu ${ }^{2}$, Prof.Dr.S.Moses Aranganathan ${ }^{3}$ \\ ${ }^{1}$ Department of Civil Engineering, Adama Science and Technology University, Adama, \\ Po.box-1888, Ethiopia, email: getfix@ rocketmail.com \\ ${ }^{2}$ Department of Civil Engineering, Addis Ababa University, Addis Ababa, \\ Po.box-32490,Ethiopia,email:dhasfaw@gmail.com \\ ${ }^{2}$ Department of Civil Engineering, Adama Science \& technology University, Adama, \\ Po.box-1888,Ethiopia,email:ermoses1954@yahoo.co.ln
}

\begin{abstract}
This paper presents simulation of Lake Tana reservoir future water use under emerging scenario with and without climate change impacts.

Two different development and climate change scenarios were developed to simulate Lake Tana water level i.e., i) Base line scenario (1991-2000), ii) Future development scenario on short term periods(2031-2040), and ii) Future development scenario on long term periods (2091-2100). River head flow estimated by Soil and Water Assessment Tool (SWAT) was used as an input to Water Evaluation And Planning (WEAP) model to simulate the Lake level for each scenario.
\end{abstract}

Based on WEAP model simulation results, demand coverage and reliability of $100 \%$ was observed in all scenarios for Tana-Beles hydropower project. For scenarios without climate change impacts, there are longer periods of time when mean monthly lake levels are below 1785 masl (i.e., the minimum lake level required for shipping). Under natural conditions (lake level without project), they exceed this level in $100 \%$.under current conditions (Base line scenario, BLS), they exceed this level in $89 \%$ of the months. In the full development scenario (FDSC'), this will decrease to $83 \%$. For all scenarios with climate change impacts, Lake water Level will not significantly be affected by climate change impacts.

Key Words: SWAT, WEAP, Lake Level, Lake Tana, Climate Change, Reliability.

\section{I.INTRODUCTION}

The increased demand of water for agriculture, industries, domestic, and power generation in Lake Tana sub-basin requires proper planning and management of water resources in the basin. The basin has more than 40 rivers inflow in to Lake Tana and about $93 \%$ of the inflow is coming from the four major rivers Gilgel Abbay, Gummera, Rib and Megech [3].
The purpose of this study is therefore applying a physically based semi distributed model called Soil and water assessment tool (SWAT), to understand the hydrology of the basin, to know the water resource potential as a whole from gauged and un-gauged catchments as well as water evaluation and planning (WEAP) model[6] were used to asses upstream catchment development and climate change impact on Lake Tana water level and to assess the sustainability of Tana -belles Hydropower plant on the basis of adjusting the operation rule of Lake Tana reservoir.

The analysis presented in this paper is the first of its kind which was done using actual data in Lake Tana subbasin. The study addresses; The assessment of water resources potential of Lake Tana basin, Assessment of Impact of upstream irrigation development on Lake Tana water level and Tana-belles Hydropower plant, Assessment of impact of climate change on Lake Tana and Beles hydro power plant with and without emerging upstream irrigation project, and assessment of the sustainability of Tana-Beles development on the basis of adjusting the operation rule of the Lake.

The output of this study can be used as an input for decision support for water resources planning, development, and management of water resources in the basin.

\section{II.STUDY AREA DESCRIPTION}


Council for Innovative Research

www.cirworld.com

Lake Tana Basin is part of the Blue Nile basin, which lies in a natural drainage basin of about $15114 \mathrm{Km}^{2}$ as per this research work using SWAT delineation. Among which about $20.47 \%$ is covered by the Lake Tana. Lake Tana basin is found in North West part of Ethiopia and it extends between $10.95^{\circ} \mathrm{N}$ to $12.78^{\circ} \mathrm{N}$ latitude and from $36.89^{\circ} \mathrm{E}$ to $38.25^{\circ} \mathrm{E}$ longitude (highlighted in fig. 1 ).

Topography is generally uniform and quite well adapted to irrigation development surrounding Lake Tana $[5,9]$. The elevation ranges between $914 \mathrm{~m}$ to $4096 \mathrm{~m}$ +MSL, which is extracted from DEM $(90 * 90 \mathrm{~m})$ resolution. There are two seasons rainy and dry. The rainy season has two periods, the little rains, during April and May, and the big rains, which last from mid- June to mid-September. The rainfall distribution in the basin is found to be a mono-modal pattern i.e. one peak value observed during rainy season especially in July, and August.

Considering the rainfall stations in the basin for a period of 1996-2006 the mean annual rainfall amount ranges
International Journal of Computers \& Technology Volume 4 No. 2, March-April, 2013, ISSN 2277-3061 between $813 \mathrm{~mm}$ in Yifag and $2328 \mathrm{~mm}$ in Enjibara. Similarly the mean annual minimum and maximum temperature ranges between $9.3{ }^{\circ} \mathrm{C}$ in Dangila and 29.6 ${ }^{\circ} \mathrm{C}$ in Gorgora respectively.

Land use of study area was classified based on Abay river master plan study conducted by BCEOM, in 19961999[2], about $51.37 \%$ of the watershed area was covered by Agriculture, $21.94 \%$ by Agro-pastoral, 20.41 $\%$ by Lake Tana, $0.39 \%$ by Agro-Sylvicultural, $0.13 \%$ by wetland, $5.47 \%$ by Pastoral, $0.15 \%$ by Sylvicultural, $0.03 \%$ by sylvo-pastoral and $0.11 \%$ by Urban.

The soil classification for the study area is also adopted from Abay river master plan study in 1996-1999 conducted by BCEOM [2]. Based on the classification Halpic luvisol which covers about $20.68 \%$ of the watershed area is considered to be the major dominant soil in the study area.

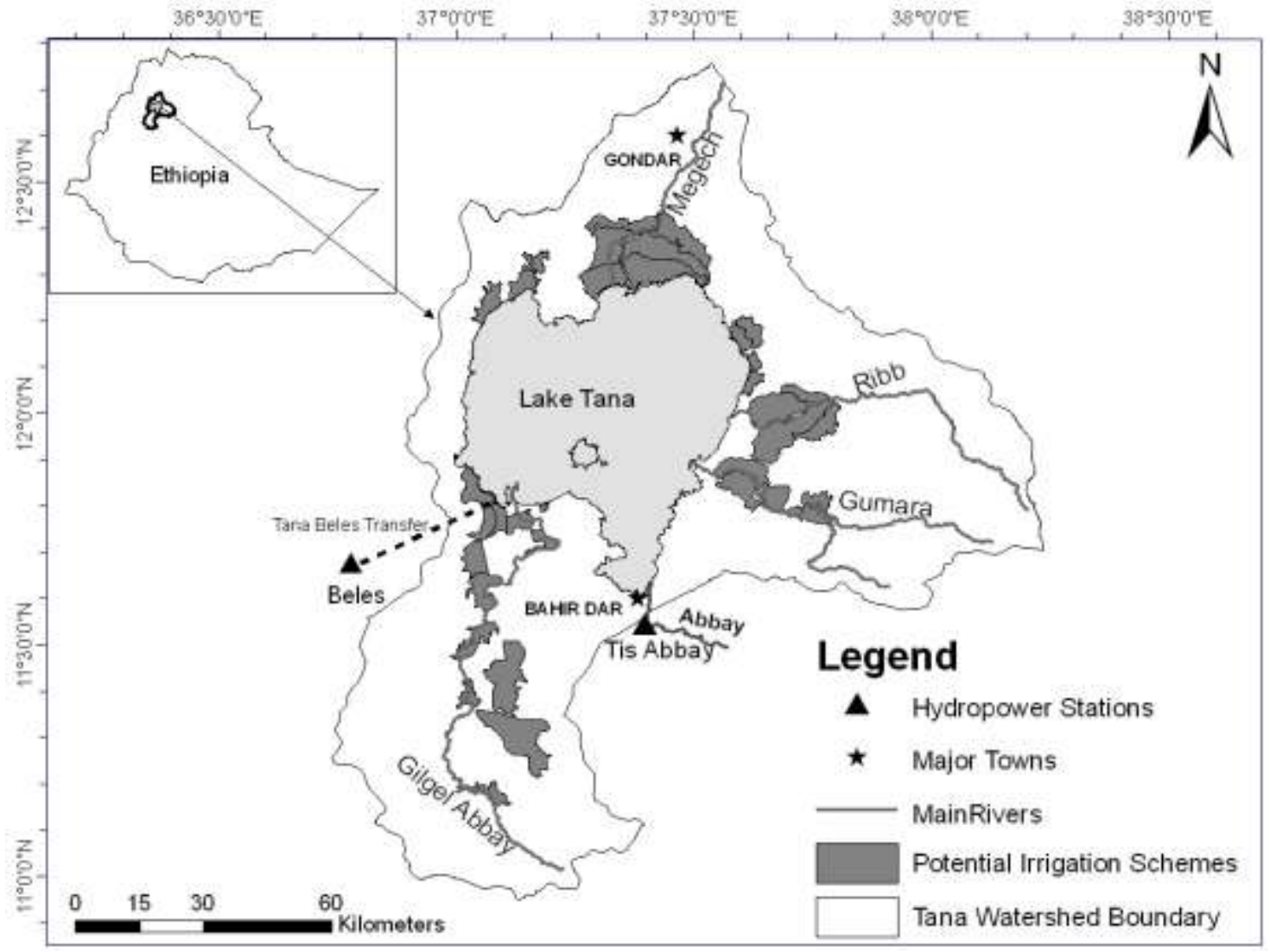

Figure 1: Location Map of Lake Tana Basin 


\section{III.METHODOLOGY}

The following flow chart indicates the overall framework of the methodology to be followed throughout the study.

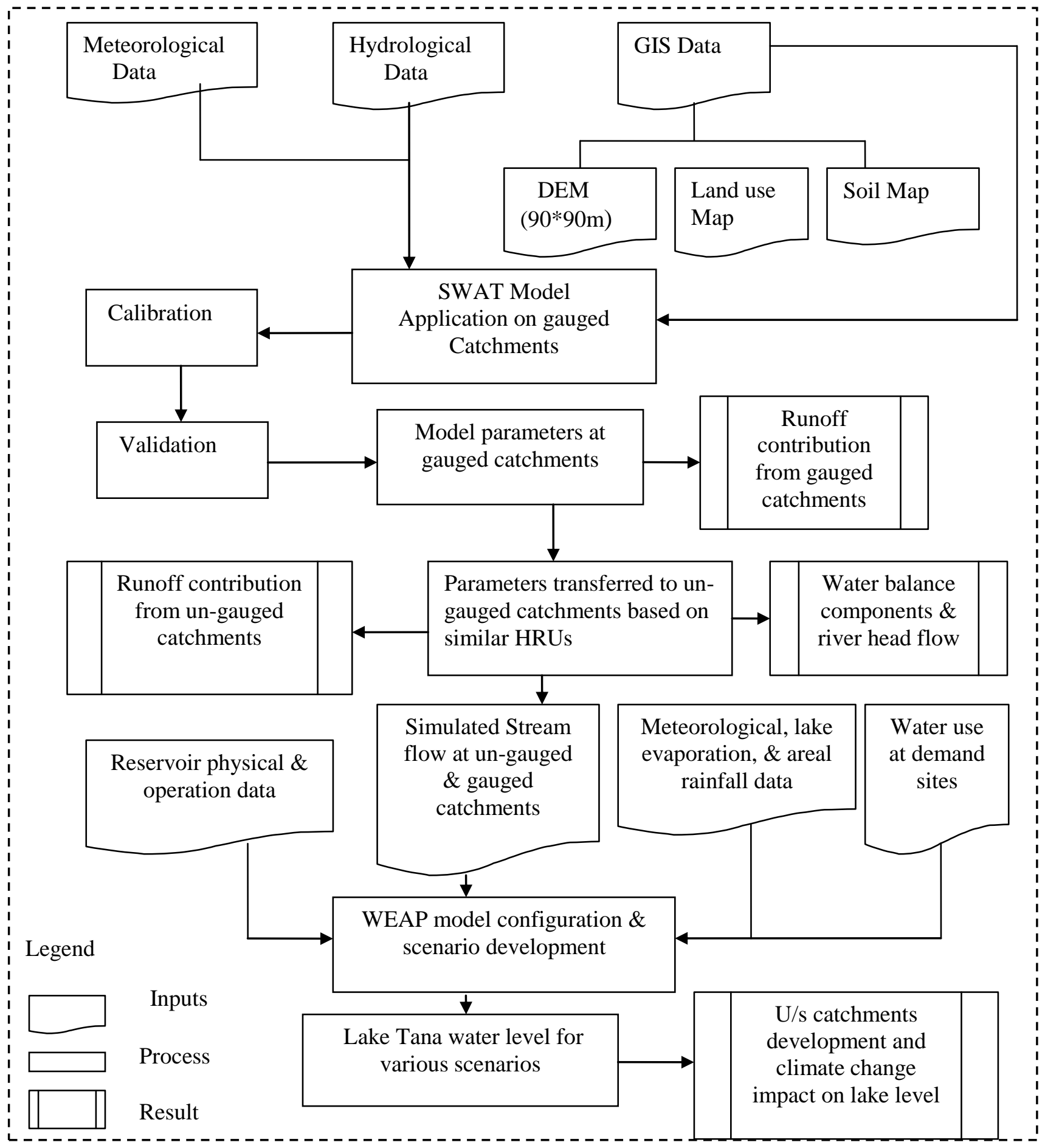

Figure 2: General frame work adopted for the study 


\section{IV.SCENARIO DEVELOPMENT}

In this study the model was set-up to simulate two scenarios based on development plans of the basin. The model is first configured to simulate a base line scenario, for which the water availability and demands can be confidently determined. It is then used to simulate for future development scenarios to assess the impact of development and climate change on the hydrology and water resources.

a) Scenario BLS: Base line scenario(1991-2000),

b) Scenario FDSC': Future development scenario (future water demand without climate change);

c) Scenario $\mathrm{FDSC}_{1}$ : Future development scenario under climate change on short term basis (20312040), and

d) Scenario $\mathrm{FDSC}_{2}$ : Future development scenario under climate change on long term basis (2091-2100).

Interventions in the water sector in Abbay basin fall in to three main areas: irrigation, hydropower, and water supply. However, water supply requirements are small relative to those for irrigation and hydropower [2]. Projects, like water supply and sanitation, that do not significantly influence the results of water availability in the basin was not also be considered.

\section{A. Scenario BLS}

This Scenario represents the existing development in the basin. Relative to the basin water resource potential; development activities achieved yet is insignificant. Koga irrigation, Tis Issat fall and Tana Beles Hydropower schemes was considered for the base line scenario. When Tana Beles transfer become operational Tiss Abbay I and II hydropower stations will be used as standby stations, only to operate as a backup system when problems in the National grid may require [2,7]. Hence they are not considered in this scenario.

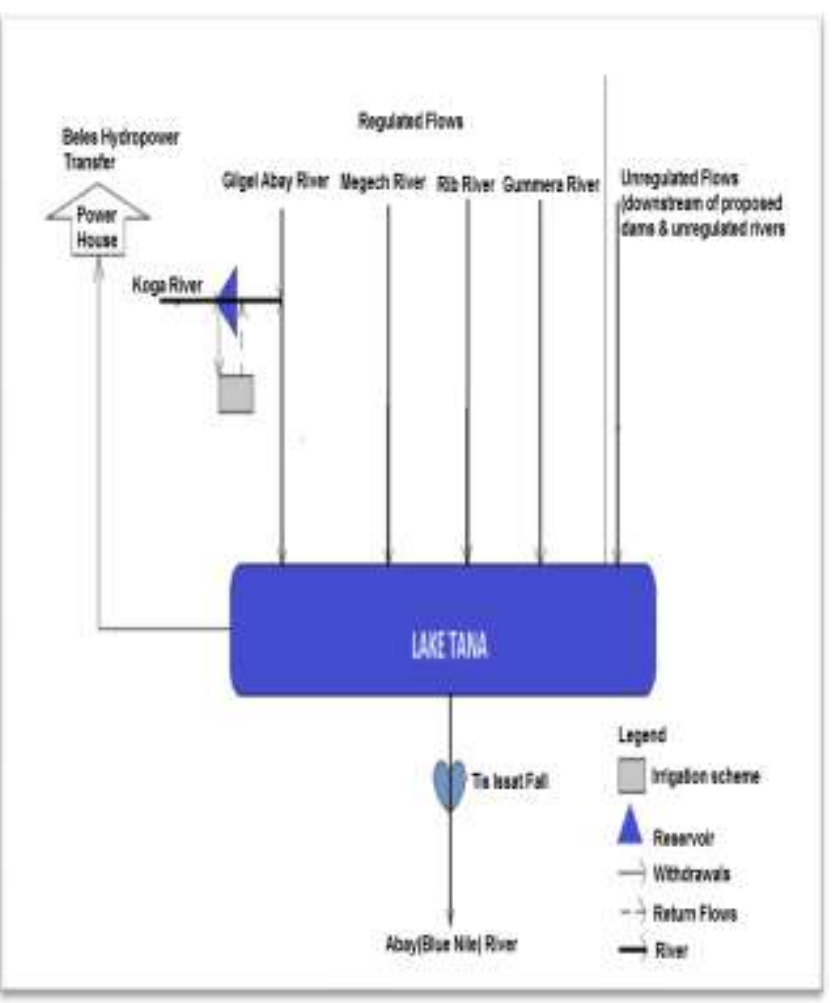

Figure 3: Schematic of the model configuration for the Current situation Scenario

B. Scenario FDSC'

This Scenario represents full development activities in the basin which are expected to be operational in future period of time. The analysis includes projects which are currently operational, ongoing development, and likely development activities. The scenario not considers the impact of climate change on hydrology and water resources in the basin.

\section{Scenario $\mathrm{FDSC}_{1} \& \mathrm{FDSC}_{2}$}

This Scenario represents full development activities which are expected to be operational in the long period of time in the future. Scenario $\mathrm{FDSC}_{1}$ represents future development scenario with climate change for time periods of 2031-2040 and scenario $\mathrm{FDSC}_{2}$ represents future development scenario with climate change for time periods of 2091-2100.The analysis includes projects which are currently operational, ongoing development, and likely development activities. The scenario considers the impact of climate change on hydrology and water resources in the basin. i.e., the climate variables are under the influence of climate change in the future. 
Council for Innovative Research

www.cirworld.com

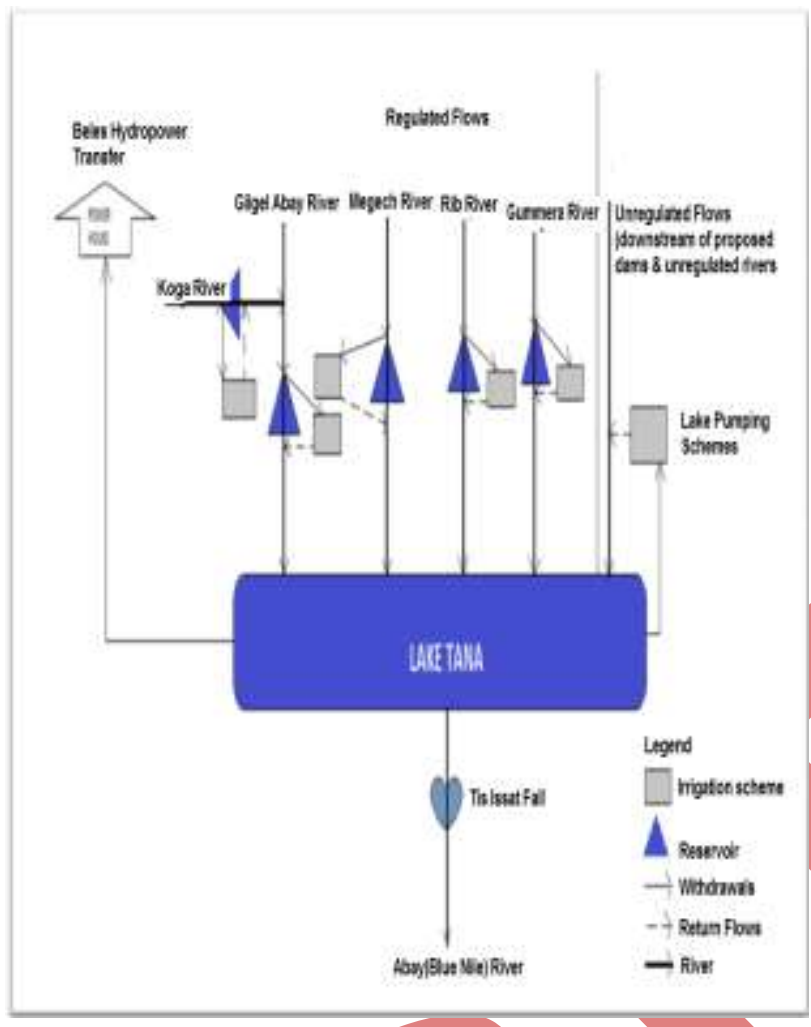

Figure 4: Schematic of the model configuration for the future development Scenario.

\section{V.RESULTS AND DISCUSION}

\section{A. Evaporation and rainfall over the lake}

From the Thissen polygon analysis, the annual average areal rainfall over the Lake for the simulation periods of (1991-2000), (2031-2040), and (2091-2100) found to be $1291 \mathrm{~mm} /$ year, $1737.693 \mathrm{~mm} /$ year, and $1690.104 \mathrm{~mm} /$ year respectively. From CROPWAT model the average annual evaporation over the Lake for the simulation periods of (1991-2000), (2031-2040), and (2091-2100) found to be $1618 \mathrm{~mm} /$ year, $1767 \mathrm{~mm} /$ year, and $1909 \mathrm{~mm} /$ year respectively.
International Journal of Computers \& Technology Volume 4 No. 2, March-April, 2013, ISSN 2277-3061

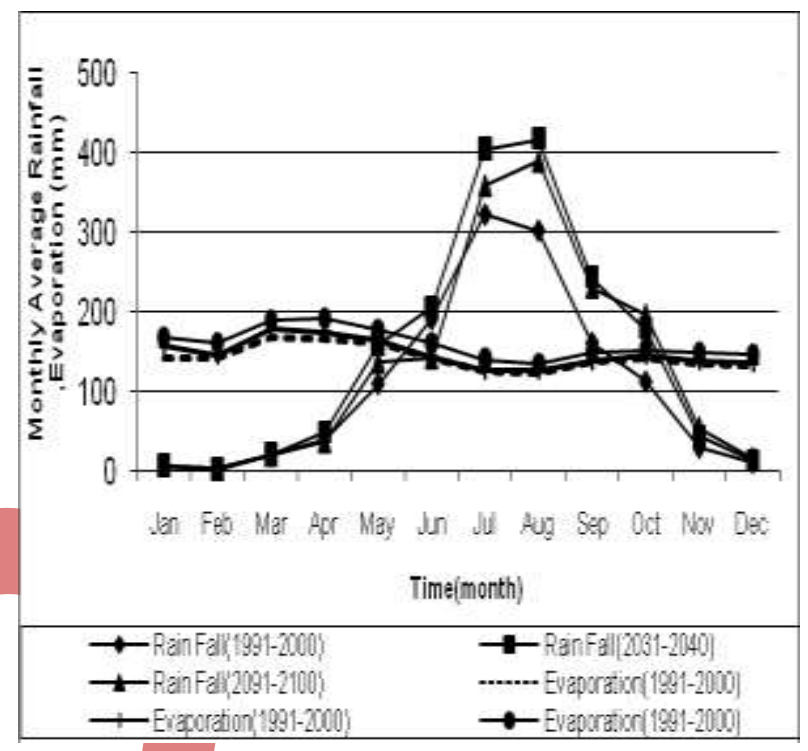

Figure 5: Monthly average rainfall and evaporation over Lake Tana.

B.Modeling of Gauged Catchments

Historical observed stream flow of Gilgel Abay at Merawi, Gummera at Bahirdar, Rib at Addiszemen and Megech at Azezo were calibrated from a period of 19962002 and validated from a period of 2003- 2005 .

Table 1: Calibration \& validation statistics of observed and simulated stream flow

\begin{tabular}{|c|c|c|c|}
\hline \multicolumn{2}{|c|}{ Average monthly flow } & \multirow[t]{2}{*}{$\mathrm{R}^{2}$} & \multirow[t]{2}{*}{ NSE } \\
\hline Observed & Simulated & & \\
\hline \multicolumn{4}{|c|}{ Gilgel Abay River (Calibration period 1996-2002) } \\
\hline 57.26 & 58.21 & 0.91 & 0.91 \\
\hline \multicolumn{4}{|c|}{ Gilgel Abay River (Validation period 2003-2005) } \\
\hline 34.64 & 32.95 & 0.93 & 0.92 \\
\hline \multicolumn{4}{|c|}{ Gummera River (Calibration period 1996-2002) } \\
\hline 37.74 & 38.8 & 0.70 & 0.70 \\
\hline \multicolumn{4}{|c|}{ Gummera River (Validation period 2003-2005) } \\
\hline 34.06 & 27.69 & 0.91 & 0.90 \\
\hline \multicolumn{4}{|c|}{ Rib River (Calibration period 1996-2002) } \\
\hline 14.93 & 15.82 & 0.82 & 0.82 \\
\hline \multicolumn{4}{|c|}{ Rib River (Validation period 2003-2005) } \\
\hline 13.88 & 13.28 & 0.84 & 0.83 \\
\hline \multicolumn{4}{|c|}{ Megech River (Calibration period 1996-2002) } \\
\hline 7.18 & 7.04 & 0.8 & 0.76 \\
\hline \multicolumn{4}{|c|}{ Megech River (Validation period 2003-2005) } \\
\hline 8.06 & 4.53 & 0.92 & 0.91 \\
\hline
\end{tabular}


Council for Innovative Research www.cirworld.com

\section{C.The inflow hydrograph from gauged and ungauged catchments}

Once the model is calibrated and verified at the gauged location the model output during that period were quantified and taken as simulated inflow series. Later this inflow series will be used for water balance analysis.

Similarly, the inflow series for ungauged catchments were done by transferring calibrated parameters having the same HRUs as gauged catchments. The total inflow in to the Lake mouth was determined after having the inflow from gauged catchments and inflow from ungauged catchments separately and later the total inflow was taken as the aggregate of inflow series from gauged and ungauged catchments.

From the model result total inflow from gauged catchments was found 2850.727MCM, 3595.137MCM, and 3311.873MCM for time period (1991-2000), (2031-2040), and (2091-2100) respectively. Total inflow from ungauged catchments was found $3759.228 \mathrm{MCM}, 5382.034 \mathrm{MCM}$, and5006.76MCM for time periods of (1991-2000), (20312040), and (2091-2100) respectively.

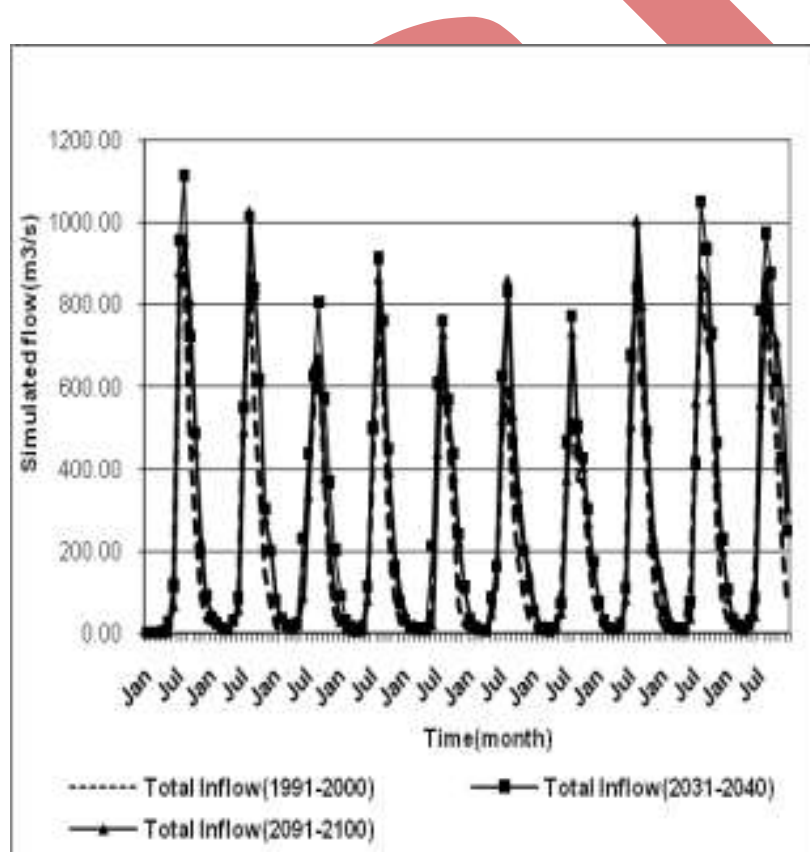

Figure 6: Total Inflow Hydrograph from gauged and ungauged catchment for all scenarios.

\section{D.Elevation Area Volume Relation ship}

The elevation Area Volume relation ship of Lake Tana reservoir was calculated for the calibration period (19962002). The polynomial fitted bathymetry by Pietrangeli and Abeyou $[1,8]$ used in this research work is as follows:

Elevation-Volume-Area relation ship as per Pietrangeli and Abeyou

Table 2: Elevation Volume Area relation ship
International Journal of Computers \& Technology Volume 4 No. 2, March-April, 2013, ISSN 2277-3061

\begin{tabular}{l|l}
\hline Pietrangeli & $E=1.08 * 10^{-9}(V)^{2}+3.88 * 10^{-4}(V)+1775.58$ \\
& $A=6.20 * 10^{-8}(V)^{2}+1.72 * 10^{-2}(V)+2516.3$ \\
\hline Abeyou & $\begin{array}{l}\mathrm{E}(\mathrm{V})^{2}+6.20^{*} 10^{-4}(\mathrm{~V})+1774.63, \\
=\end{array}$ \\
& $\begin{array}{l}\text { A } \\
6(\mathrm{~V})^{2}+1.65 * 10^{-1}(\mathrm{~V})+1147.51\end{array}$ \\
\hline
\end{tabular}

Where E= Lake level elevation, m. +MSL $\mathrm{A}=$ Surface area of the Lake, $\mathrm{Km}^{2}$ $\mathrm{V}=$ Lake volume, MCM

The basic equation used in the water balance:

$S_{t}=S_{t-1}+I(t)+P(t)-O(t)-E(t)+G_{i n}-G_{\text {out }}-\Delta \mathrm{s}$

Where:

$S_{t}=$ Lake storage volume at the end of current month, $S_{t-1}=$ Lake storage volume at the end of previous month, $\mathrm{I}(\mathrm{t})=$ Simulated inflow volume from gauged and un-gauged catchments at current month,

$\mathrm{O}(\mathrm{t})=$ Outflow volume at the Lake outlet,

$P(t)=$ Areal rainfall volume on the Lake surface,

$\mathrm{E}(\mathrm{t})=$ Evaporation volume on the Lake surface,

$G_{i n}(t)=$ Ground water inflow in to the Lake at the end of current month,

$G_{\text {out }}(\mathrm{t})=$ Ground water outflow from the Lake at the end of current month.

$\Delta \mathrm{s}=$ other losses.

The water balance terms were computed using EXCEL spread sheet model and the monthly water balance result obtained by using the relation ship developed by Abeyou, (2008) has been best fitted than Pietrangeli, (1990). 
Council for Innovative Research www.cirworld.com

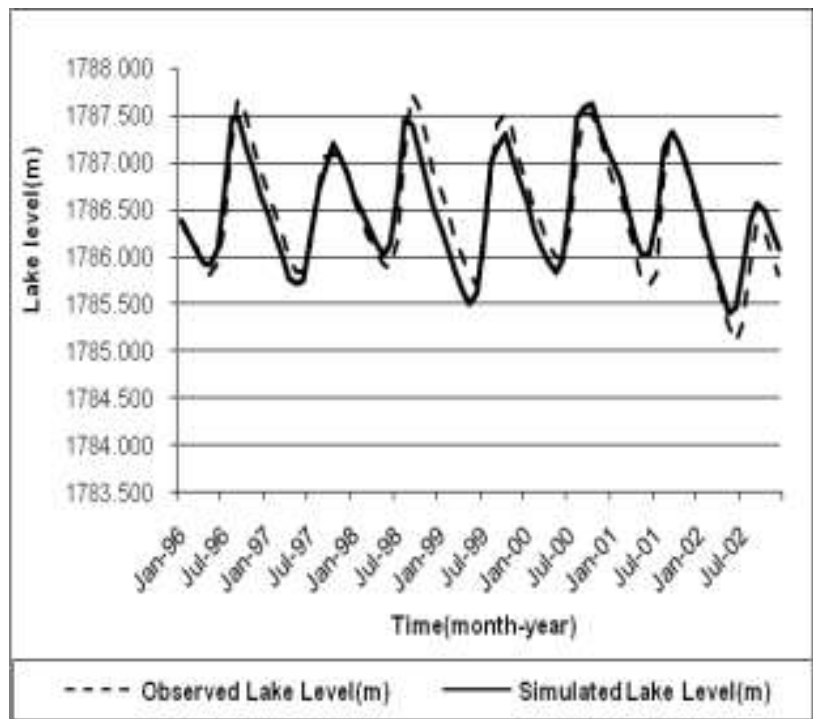

Figure 7: Observed and Simulated Lake Level with out project for the period 1996-2002.

Table 3: Lake Tana Annual water balance components simulated from 1996-2002

\begin{tabular}{|l|l|}
\hline Water balance components & $\mathbf{m m} /$ year \\
\hline Lake areal rainfall & +1291 \\
\hline Gauged River inflow & +822 \\
\hline Un-gauged river inflow & +1297 \\
\hline Lake Evaporation & -1618 \\
\hline River outflow & -1725 \\
\hline Change in storage & 67 \\
\hline
\end{tabular}

E.Upstream Catchment Development Impact on Lake Tana Water Level

Figure 8 presents a comparison of the time series of simulated lake levels with project and without project for all scenarios. The results indicate the decline in mean annual lake levels, and consequently lake area, as water resources development in the catchment increases. As
International Journal of Computers \& Technology Volume 4 No. 2, March-April, 2013, ISSN 2277-3061

water resources development increases there are longer periods of time when mean monthly

lake levels are below 1785 masl (i.e., the minimum lake level required for shipping) [4]. Under natural conditions (lake level without project), they exceed this level in $100 \%$.under current conditions (Base line scenario, BLS), they exceed this level in $89 \%$ of the months. In the full development scenario (FDSC'), this will decrease to $83 \%$.

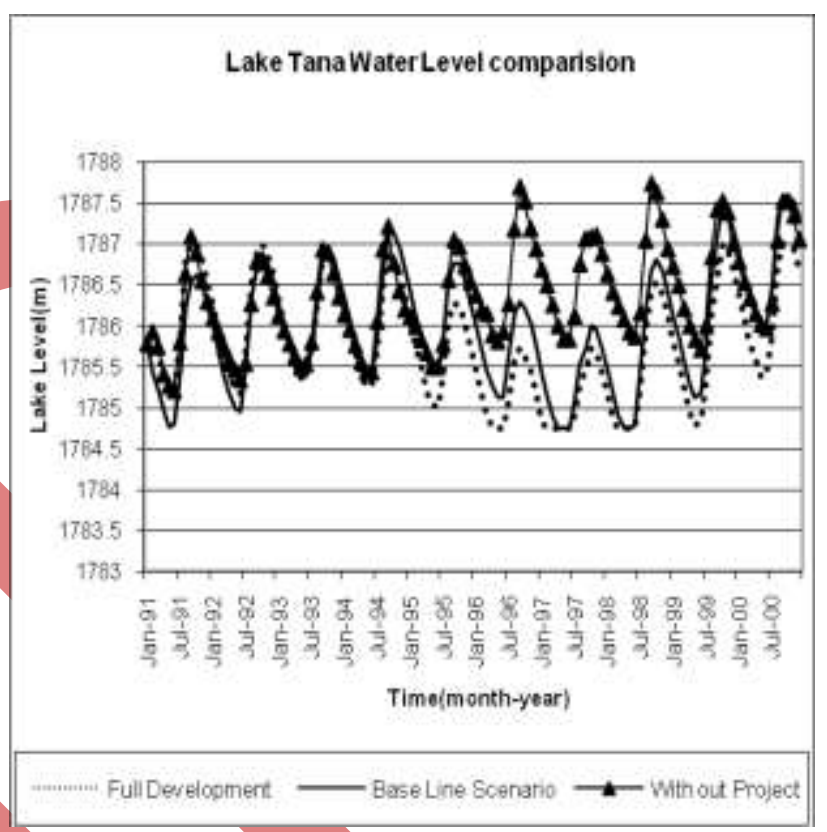

Figure 8: Comparison of simulated lake level with project and without project (1991-2000)

F.Upstream Catchment Development Impact on Tana-Beles Hydropower Plant

Table 4 and 5 presents annual unmet demand in million cubic meter for base line scenario and full development scenario respectively. From the result, 100 percent reliability of Tana-Beles hydropower project was observed for base line scenario and full development scenario.

Table 4: Yearly unmet demands (MCM) for BLS scenario (1991-2000)

\begin{tabular}{|llllllllllll|} 
Scheme & $1991 *$ & $1992 *$ & $\mathbf{1 9 9 3}$ & $\mathbf{1 9 9 4}$ & $\mathbf{1 9 9 5}$ & $\mathbf{1 9 9 6}$ & $\mathbf{1 9 9 7}$ & $\mathbf{1 9 9 8}$ & $\mathbf{1 9 9 9}$ & $\mathbf{2 0 0 0}$ & Sum \\
\hline $\begin{array}{l}\text { Tana Beles } \\
\text { Hydropower }\end{array}$ & 0 & 0 & 0 & 0 & 0 & 0 & 0 & 0 & 0 & 0 & 0 \\
\hline $\begin{array}{l}\text { Koga } \\
\text { Irrigation }\end{array}$ & 47.4446 & 0.00407 & 0 & 0 & 0 & 0 & 0 & 0 & 0 & 0 & 47.44 \\
\hline Sum & 47.4446 & 0.00407 & 0 & 0 & 0 & 0 & 0 & 0 & 0 & 0 & 47.44 \\
\hline
\end{tabular}

$1991 * 1992 *$ shows the "warm up" period for reservoirs filling and not considered for analysis

Table 5: Yearly unmet demands (MCM) for FDSC' scenario (1991-2000) 


\begin{tabular}{|llllllllllll|}
\hline Scheme 1991* & $\mathbf{1 9 9 2}$ & $\mathbf{1 9 9 3}$ & $\mathbf{1 9 9 4}$ & $\mathbf{1 9 9 5}$ & $\mathbf{1 9 9 6}$ & $\mathbf{1 9 9 7}$ & $\mathbf{1 9 9 8}$ & $\mathbf{1 9 9 9}$ & $\mathbf{2 0 0 0}$ & Sum \\
\hline $\begin{array}{l}\text { Tana Beles } \\
\text { Hydropower }\end{array}$ & 0 & 0 & 0 & 0 & 0 & 0 & 0 & 0 & 0 & 0 & 0 \\
\hline $\begin{array}{l}\text { Gilgel Abay } \\
\text { Irrigation }\end{array}$ & 91.37 & 46.72 & 34.31 & & 0 & 0 & 0 & 0 & 0 & 0 & 172.40 \\
\hline $\begin{array}{l}\text { Gumera } \\
\text { Irrigation }\end{array}$ & 26.01 & 0 & 0 & 0 & 0 & 0 & 0 & 0 & 0 & 0 & 26.01 \\
\hline $\begin{array}{l}\text { Koga } \\
\text { Irrigation }\end{array}$ & 48.300 & 33.21 & 0 & 0 & 0 & 0 & 0 & 0 & 0 & 0 & 81.51 \\
\hline $\begin{array}{l}\text { Megech } \\
\text { Irrigation }\end{array}$ & 39.639 & 29.15 & 13.61 & 0 & 0 & 0 & 0 & 0 & 0 & 0 & 82.41 \\
\hline Rib Irrigation & 166.94 & 42.64 & 19.86 & & 0 & 0 & 0 & 0 & 0 & 0 & 229.44 \\
\hline $\begin{array}{l}\text { Tana Pump } \\
\text { Irrigation }\end{array}$ & 0 & 0 & 0 & 0 & 0 & 0 & 0 & 0 & 0 & 0 & 0 \\
\hline Sum & 372.26 & 151.73 & 67.79 & 0 & 0 & 0 & 0 & 0 & 0 & 0 & 591.79 \\
\hline
\end{tabular}

1991* 1992* 1993* shows the "warm up" period for reservoirs filling and not considered for analysis.

\section{G.Climate Change Impacts on Lake Tana Water Level}

Currently, there is great uncertainty about the likely impacts of climate change in the Abay Basin. Results from Global climate models (GCMs) are contradictory; some show increases in rainfall whilst others show decreases. A recent study of 17 GCMs indicated that precipitation changes between $-15 \%$ and $+14 \%$ which, compounded by the high climatic sensitivity of the basin [4].

Generally there is an increasing trend in both precipitation and runoff in the basin for the time

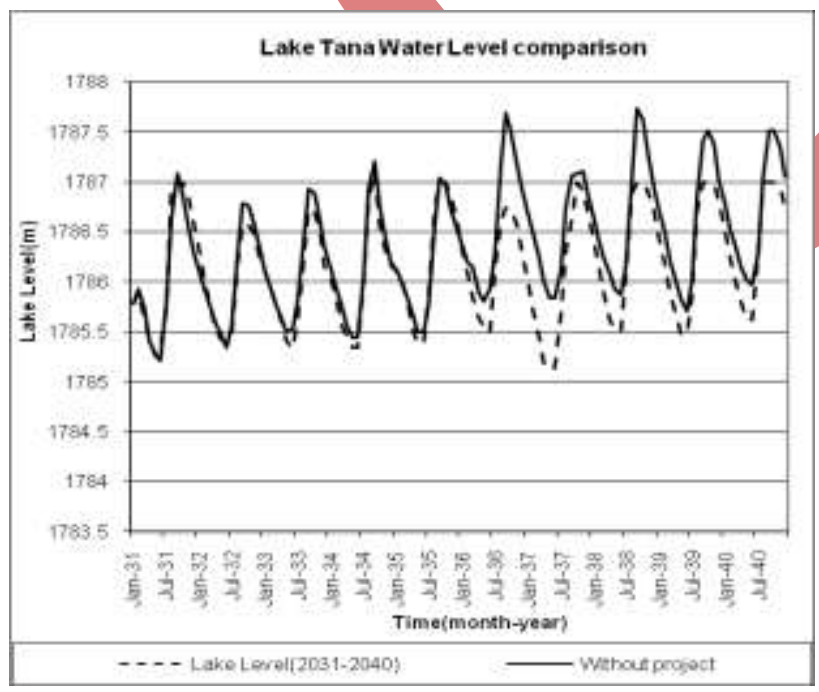

Figure 9: Comparison of simulated Lake Levels with and without project (2031-2040) period of 2031-2040 and 2091-2100. PET and reservoir evaporation shows an increasing trend for all future scenarios. The cumulative impacts of these hydrologic parameters on Lake water Level were checked using WEAP simulation model.

The results of the WEAP model simulation shows that Lake water Level will not significantly be affected by climate change impacts for all future scenarios. Figure 9 and 10 presents a comparison of the time series of simulated lake levels for all future scenarios with and without project.

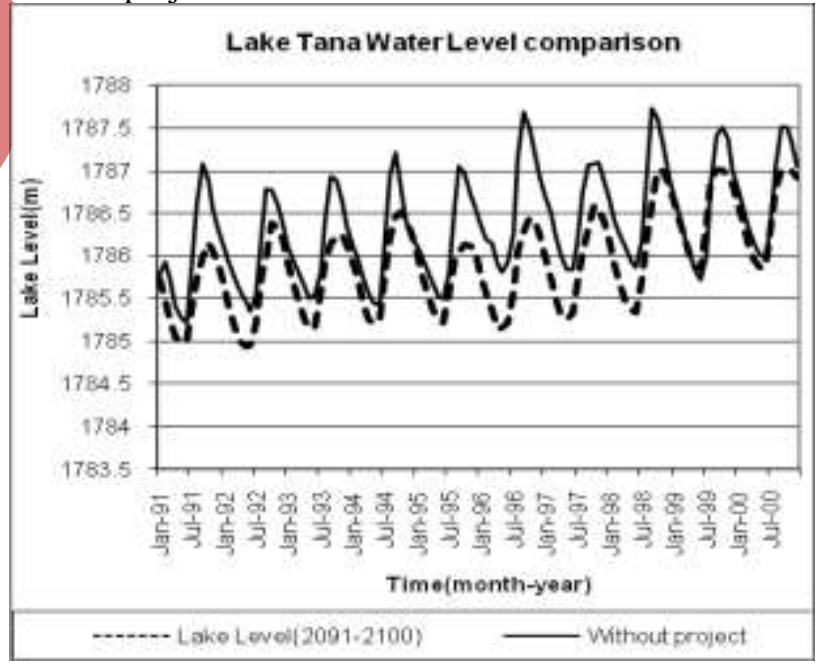

Figure 10: Comparison of simulated Lake Levels with and without project (2091-2100) 
Council for Innovative Research

www.cirworld.com

H.Climate Change Impacts on Tana-Beles Hydropower Project

The result shows climate change impacts are not significant in the basin and hence, there is no problem of
International Journal of Computers \& Technology

Volume 4 No. 2, March-April, 2013, ISSN 2277-3061

Table 6: Yearly unmet demands (MCM) for $\mathrm{FDSC}_{1}$ scenario (2031-2040

\begin{tabular}{|c|c|c|c|c|c|c|c|c|c|c|c|}
\hline Scheme & $2031 *$ & 2032* & 2033 & 2034 & 2035 & 2036 & 2037 & 2038 & 2039 & 2040 & Sum \\
\hline $\begin{array}{l}\text { Tana Beles } \\
\text { Hydropower }\end{array}$ & 0 & 0 & 0 & 0 & 0 & 0 & 0 & 0 & 0 & 0 & 0 \\
\hline $\begin{array}{ll}\text { Gilgel } \\
\text { Irrigation }\end{array}$ & 97.63 & 0.002 & 0 & $\overline{0}$ & 0 & $\overline{0}$ & 0 & 0 & 0 & 0 & 97.63 \\
\hline $\begin{array}{l}\text { Gummera } \\
\text { Irrigation }\end{array}$ & 25.42 & 0 & 0 & 0 & $\overline{0}$ & $\overline{0}$ & 0 & 0 & 0 & 0 & 25.42 \\
\hline Koga Irrigation & 48.14 & 0.004 & 0 & 0 & 0 & 0 & 0 & 0 & 0 & 0 & 48.14 \\
\hline $\begin{array}{l}\text { Megech } \\
\text { Irrigation }\end{array}$ & 39.44 & 0.01 & , & 4 & 0 & 0 & 0 & 0 & 0 & 0 & 39.45 \\
\hline Rib Irrigation & 164.12 & 0.99 & 0 & $\overline{0}$ & 0 & 0 & 0 & 0 & 0 & 0 & 165.11 \\
\hline $\begin{array}{ll}\text { Tana } & \text { Pump } \\
\text { Irrigation } & \\
\end{array}$ & 0 & & 0 & 0 & & $\overline{0}$ & 0 & 0 & 0 & 0 & 0 \\
\hline Sum & 374.77 & 1.01 & 0 & 0 & 0 & 0 & 0 & $\overline{0}$ & $\overline{0}$ & 0 & 377.7 \\
\hline
\end{tabular}

$2031 * 2032 *$ shows the "warm up" period for reservoirs filling and not considered for analysis

Table 7: Yearly unmet demands (MCM) for FDSC 2 scenario (2091-2100)

\begin{tabular}{|lllllllllllll|}
\hline $\begin{array}{l}\text { Scheme } \\
\text { 2091* }\end{array}$ & $\mathbf{2 0 9 2} *$ & $\mathbf{2 0 9 3}$ & $\mathbf{2 0 9 4}$ & $\mathbf{2 0 9 5}$ & $\mathbf{2 0 9 6}$ & $\mathbf{2 0 9 7}$ & $\mathbf{2 0 9 8}$ & $\mathbf{2 0 9 9}$ & $\mathbf{2 1 0 0}$ & Sum \\
$\begin{array}{l}\text { Hana Beles } \\
\text { Hydropower }\end{array}$ & 0 & 0 & 0 & 0 & 0 & 0 & 0 & 0 & 0 & 0 & 0 \\
\hline $\begin{array}{l}\text { Gilgel Abay } \\
\text { Irrigation }\end{array}$ & 106.71 & 0.006 & 0 & 0 & 0 & 0 & 0 & 0 & 0 & 0 & 106.71 \\
\hline $\begin{array}{l}\text { Gummera } \\
\text { Irrigation }\end{array}$ & 26.14 & 0.01 & 0 & 0 & 0 & 0 & 0 & 0 & 0 & 0 & 26.15 \\
\hline $\begin{array}{l}\text { Koga } \\
\text { Irrigation }\end{array}$ & 48.30 & 0 & 0 & 0 & 0 & 0 & 0 & 0 & 0 & 0 & 48.31 \\
\hline $\begin{array}{l}\text { Megech } \\
\text { Irrigation }\end{array}$ & 39.64 & 30.41 & 15.74 & 0 & 0 & 0 & 0 & 0 & 0 & 0 & 85.80 \\
\hline $\begin{array}{l}\text { Rib } \\
\text { Irrigation }\end{array}$ & 167.93 & 19.27 & & 0 & 0 & 0 & 0 & 0 & 0 & 0 & 187.20 \\
\hline $\begin{array}{l}\text { Tana Pump } \\
\text { Irrigation }\end{array}$ & 0 & 0 & 0 & 0 & 0 & 0 & 0 & 0 & 0 & 0 & 0 \\
\hline Sum & 388.72 & 49.70 & 15.74 & 0 & 0 & 0 & 0 & 0 & 0 & 0 & 454.18 \\
\hline
\end{tabular}


Council for Innovative Research

www.cirworld.com

\section{VI.SUMMARY AND CONCLUSION}

A cascade of two models was used in this study. The SWAT model was setup from January 1985 December 2006.Calibration and validation was done for seven years monthly time step (1996-2002) and three years monthly time step (2003-2005) respectively. After modeling the gauged watershed, calibrated parameters were transferred to ungauged watershed by lumping the parameters having the same hydrologic response unit (HRUs). The model output indicates that, the total annual inflow volume from gauged and ungauged catchments estimated to be $6229.115 \mathrm{MCM}$ for calibration period. From the Thissen polygon analysis, the annual average areal rainfall over the Lake for the simulation periods of (1991-2000), (2031-2040), and (2091-2100) found to be $1291 \mathrm{~mm} /$ year, $1737.693 \mathrm{~mm} /$ year, and 1690.104 $\mathrm{mm} /$ year respectively. From CROPWAT model the average annual evaporation over the Lake for the simulation periods of (1991-2000), (2031-2040), and (2091-2100) found to be $1618 \mathrm{~mm} /$ year, 1767 $\mathrm{mm} /$ year, and $1909 \mathrm{~mm} /$ year respectively.

Water demand analysis were done by using WEAP Simulation Model for entire projects in the basin for three different development scenarios, which will assist the water experts and decision makers in making a realistic estimate of water availability and allocation.

The WEAP model simulation results indicate the decline in mean annual lake levels, and consequently lake area, as water resources development in the catchment increases. As water resources development increases there are longer periods of time when mean monthly lake levels are below 1785 masl (i.e., the minimum lake level required for shipping). Under natural conditions (lake level without project), they exceed this level in $100 \%$. Under current conditions (Base line scenario, BLS), they exceed this level in $89 \%$ of the months. In the full development scenario (FDSC ${ }^{\prime}$ ), this will decrease to $83 \%$. The results of the WEAP model simulation shows that Lake water Level will not significantly be affected by climate change impacts for all future scenarios. By giving higher priority for hydropower schemes than irrigation schemes, the demand coverage and reliability of 100 percent was observed for Tana Beles hydropower project under all scenarios with and without climate change.
International Journal of Computers \& Technology Volume 4 No. 2, March-April, 2013, ISSN 2277-3061

\section{REFERENCES}

[1] Abeyou W., (2008). Hydrological balance of Lake

Tana, Upper Blue Nile Basin, Ethiopia, a M.Sc. thesis,

International Institute for Geo-information science and

Earth observation, Netherlands.

[2] BCEOM (1999): Abbay River Basin Integrated Development Master Plan Project and Associates (1999).

[3] Kebede, S.; Travi, Y.; Alemayehu, T.; Marc, V (2006). Water Balance of Lake Tana and its Sensitivity to fluctuations in rainfall, Blue Nile Basin, Ethiopia. Journal of hydrology 316: 233247.

[4] McCartney; Alemayehu; Shiferaw; Awulachew, S.B. (2010). Evaluation of Current and Future Water Resources Development in the Lake Tana basin, Ethiopia. Colombo, Srilanka: International Water Management Institute.39p. (IWMI Research Report 134).

[5] MoWR (Ministry of Water Resources) (1998). Abbay River Basin Integrated Development Mater Plan Project: Phase 2, vol. VI, Water Resources Development, part 2, Large Irrigation and Hydropower Dams. Report, Addis Ababa, Ethiopia.

[6] SEI (Stockholm Environment Institute).(2007). WEAP: Water Evaluation and Planning System user guide. Boston, Stockholm Environment Institute.

[7] SMEC (Snowy Mountains Engineering Corporation). (2008): Hydrological Study of the Tana - Beles Sub-basins, main report. Addis Ababa, Ethiopia: Ministry of Water Resources.

[8] Studio Pietrangeli, (1990). Tana Beles Project studies document.

[9] WWDSE (Water Works Design and Supervision Enterprise) and TAHAL Consulting Engineers Ltd. (2008). Lake Tana sub-basin four dams project, final feasibility report for Megech Irrigation Project, Vol. III: hydrological report. Addis Ababa, Ethiopia. 